
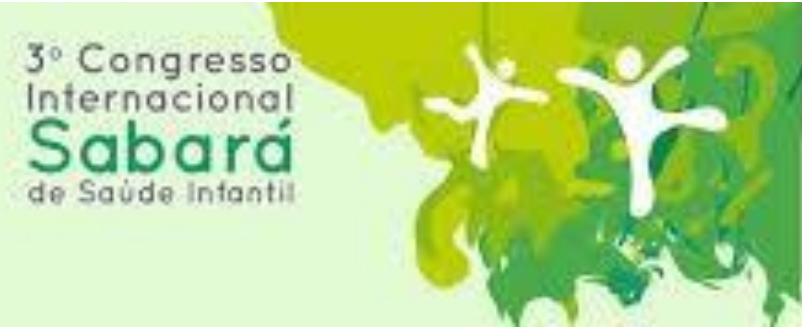

\title{
EXPERIÊNCIA DE VISITAR A IRMA NA UNIDADE DE TERAPIA INTENSIVA PEDIÁTRICA REVELADA POR MEIO DO BRINQUEDO TERAPÊUTICO DRAMÁTICO
}

\section{Pôster}

Autores deste trabalho:

GLICINIA ELAINE ROSILHO PEDROSO: Enfermeira. Docente do Curso de Graduação em Enfermagem da Universidade Metodista de Piracicaba - UNIMEP. Doutoranda em Ciências - Faculdade de Enfermagem - UNICAMP. Membro do Grupo de Estudos da Criança, Adolescente e Família - GECAF - UNICAMP.

Camila Cazissi da Silva: Enfermeira assistencial da Unidade de Terapia Intensiva do Hospital de Clínicas - Unicamp. Mestranda em Ciências - Faculdade de Enfermagem UNICAMP. Membro do Grupo de Estudos da Criança, Adolescente e Família - GECAF - UNICAMP.

Luciana de Lione Melo: Enfermeira. Professora Doutora da Faculdade de Enfermagem - Unicamp. Pós-doutoranda do Programa de Pós Graduação em Enfermagem da UNIFESP. Líder do Grupo de Estudos da Criança, Adolescente e Família - GECAF UNICAMP e do Grupo de Estudos do Brinquedo - GEBrinq - UNIFESP.

Área do Trabalho: Enfermagem pediátrica

Número de inscrição: 5138

Data da submissão:30/08/2016 às 10:28

\section{Justificativa}

A visita de menores de 12 anos a irmãos hospitalizados em unidades pediátricas é algo raro nos hospitais brasileiros. Contudo, crianças que necessitam ser hospitalizadas, em especial em terapia intensiva, sentem o impacto do afastamento dos familiares, principalmente dos irmãos. O risco de contaminação e transmissão de doenças e o comportamento desconhecido dos pequenos são justificativas para limitar a entrada de crianças em hospitais, desconsiderando questões emocionais que envolvem crianças hospitalizadas e suas famílias. Quando se permite a visita de irmãos menores, estes, sendo crianças, necessitam de informações em linguagem própria à idade. Uma das possibilidades de comunicação com a criança é o brinquedo terapêutico, um brinquedo estruturado capaz de aliviar a ansiedade gerada por experiências atípicas a idade. Uma de suas modalidades, a dramática, propicia à criança dramatizar experiências novas.

\section{Objetivo(s)}

Descrever a experiência da criança em visitar a irmã na unidade de terapia intensiva pediátrica por meio de brinquedo terapêutico dramático. 


\section{Método(s)}

Relato de experiência de pós-graduandos em enfermagem, que utilizaram o brinquedo terapêutico dramático com uma criança em idade pré-escolar que visitou a irmã na unidade de terapia intensiva pediátrica. Foram realizadas três sessões de brinquedo terapêutico dramático, sendo uma após a primeira visita, onde não houve preparo prévio e as outras duas sessões, após novas visitas com preparo utilizando o brinquedo terapêutico instrucional.

\section{Resultado(s)}

Durante as sessões, mesmo sem história pregressa de hospitalização, a criança brincou, quase que exclusivamente com materiais hospitalares, sempre em alusão a irmã hospitalizada. Demonstrou receio significativo em aproximar-se da irmã devido à alopecia, porém não fez menção aos aparelhos e/ou aos dispositivos. Mostrou-se relutante em reencontrar a irmã, mas paulatinamente, passou a expressar maior compreensão da situação de hospitalização.

\section{Conclusão(ões)}

O brinquedo terapêutico mostrou-se um excelente recurso para compreender sentimentos e comportamentos da criança, possibilitando diminuir o medo e a ansiedade em relação à irmã hospitalizada. Como estratégia de comunicação e informação, oferece oportunidades únicas de interação entre enfermeiras e crianças pequenas. 